\title{
The impact of COVID-19 pandemic on nitrogen dioxide levels in Nigeria
}

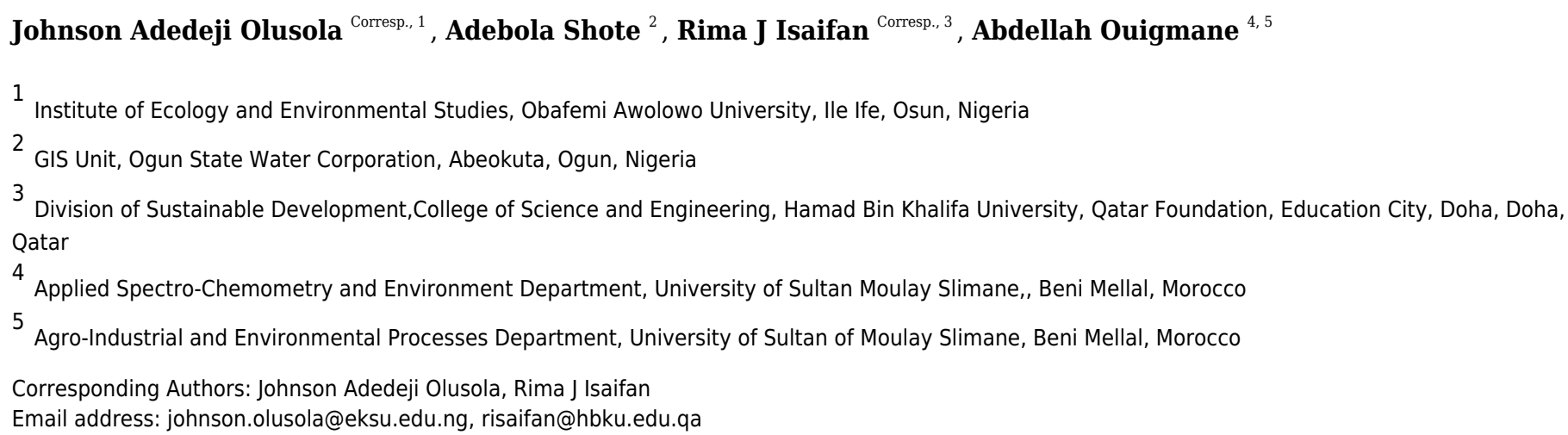

The Coronavirus disease (COVID-19) has been transmitted worldwide over a very short time after it originated in China in December 2019. In an attempt to control its spread and reduce its health impacts, several countries including those in the African continent imposed restrictive measures that was termed "lockdown". The outcomes of this lockdown have been reported to be beneficial to air quality worldwide. The main objective of this study is to assess the impact of lockdown due to COVID-19 on nitrogen dioxide $\left(\mathrm{NO}_{2}\right)$ levels over six major cities in Nigeria. Maps extracted from satellite (Sentinel - 5P) were used to indicate the significant reduction in the level of $\mathrm{NO}_{2}$ in the selected cities in Nigeria during two time-intervals, pre-lockdown (December, 2019) and during lockdown (April, 2020). The results show a significant reduction in $\mathrm{NO}_{2}$ levels during the lockdown period compared with its levels during the pre-lockdown period in 2019. The reduction in $\mathrm{NO}_{2}$ concentration levels during lockdown is likely due to less traffic, social distancing and restrictions on business and human activities. Although COVID-19 has negatively impacted the health and economic status of all regions worldwide, it has benefited some aspects of air quality in most countries including Nigeria. This indicates that anthropogenic activities may be managed to reduce air pollution and positively impact the health of human beings. 
3 Johnson Adedeji Olusola ${ }^{1}$, Shote Adebola Adekunle ${ }^{2}$, Abdellah Moha Ouigmane ${ }^{3,4}$, Rima Jamal Isaifan $^{5}$

$6{ }^{1}$ Institute of Ecology and Environmental Studies, Obafemi Awolowo University, Ile Ife, Osun,

$7 \quad$ Nigeria

$8{ }^{2}$ GIS Unit, Ogun State Water Corporation, Abeokuta, Ogun State, Nigeria

$9{ }^{3}$ Applied Spectro-Chemometry and Environment Department, University of Sultan Moulay

10 Slimane, Beni Mellal, Morocco

$11{ }^{4}$ Agro-Industrial and Environmental Processes Department, University of Sultan of Moulay

12 Slimane Beni Mellal, Morocco

$13{ }^{5}$ Division of Sustainable Development, College of Science and Engineering, Hamad Bin Khalifa 14 University, Qatar Foundation, Education City, Doha, Qatar

16 Corresponding Author:

17 Rima Isaifan ${ }^{5}$

18 Hamad Bin Khalifa University, Qatar Foundation, Education City, Doha, Qatar

19 Email address: risaifan@hbku.edu.qa

\section{Abstract}


24 The Coronavirus disease (COVID-19) has been transmitted worldwide over a very short time after 25 it originated in China in December 2019. In an attempt to control its spread and reduce its health 26 impacts, several countries including those in the African continent imposed restrictive measures 27 that was termed "lockdown". The outcomes of this lockdown have been reported to be beneficial 28 to air quality worldwide. The main objective of this study is to assess the impact of lockdown due 29 to COVID-19 on nitrogen dioxide $\left(\mathrm{NO}_{2}\right)$ levels over six major cities in Nigeria. Maps extracted 30 from satellite (Sentinel - 5P) were used to indicate the significant reduction in the level of $\mathrm{NO}_{2}$ in 31 the selected cities in Nigeria during two time-intervals, pre-lockdown (December, 2019) and 32 during lockdown (April, 2020). The results show a significant reduction in $\mathrm{NO}_{2}$ levels during the 33 lockdown period compared with its levels during the pre-lockdown period in 2019. The reduction 34 in $\mathrm{NO}_{2}$ concentration levels during lockdown is likely due to less traffic, social distancing and restrictions on business and human activities. There could be an element of uncertainty in the results due to seasonality, as the comparison is done with a different season. However, the magnitude of change due to lockdown is probably much higher than the seasonal variability.

Although COVID-19 has negatively impacted the health and economic status of all regions worldwide, it has benefited some aspects of air quality in most countries including Nigeria. This indicates that anthropogenic activities may be managed to reduce air pollution and positively

Keywords: Covid-19, lockdown, air quality, Nitrogen dioxide, World Health Organization, 5-P

Sentinel, Africa, Health, Nigeria, pollution

\section{Introduction}

The novel coronavirus (COVID-19) has changed human behavior and resulted in hundreds of thousands of deaths, caused excessive loss of jobs, and reduced social and economic activities.

52 The first confirmed case of this deadly virus was seen in Wuhan province in China in December, 532019 before it spread across the globe and was declared by the World Health Organization (WHO) as a pandemic in March 2020 (Isaifan, 2020). Severe Acute Respiratory Syndrome Coronavirus-2 
55 (SARS CoV-2) has been confirmed as the pathogen responsible for COVID-19 (Zhoua et al., 56 2020) which had previously caused Severe Acute Respiratory Syndrome (SARS) (Peiris et al., 57 2004) and Middle East Respiratory Syndrome (MERS) (Zaki et al., 2012).

58 Nigeria reported the first case of COVID-19 on the $27^{\text {th }}$ of February 2020 , following the arrival of 59 an Italian citizen in Lagos from Europe (Kalu, 2020). Due to contact with the first case, a second 60 confirmed case was reported in Ogun State, and then more cases quickly emerged (Kalu, 2020).

61 Eventually, COVID-19 spread to all the States in the Federal Republic of Nigeria as reported by

62 the Nigerian Center for Diseases Control (NCDC) which showed that all the states in Nigeria had 63 one or more cases, with a confirmed fatality rate (CFR) of $3 \%$. Accordingly, the Federal 64 Government of Nigeria formed the Presidential Task Force (PTF), to oversee the pandemic. In the 65 course of this action, a 2-week lockdown was announced by the Nigerian Government on March $6630^{\text {th }}, 2020$, in three states; Lagos, Ogun and Abuja, the first states hit by the virus before the 67 lockdown was further extended to the whole country. Afterwards, there have been a series of 68 extensions of this lockdown by both Federal and State Governments of Nigeria. Recently, the 69 lockdown has been gradually eased in phases to allow basic activities and normal business. The 70 World Health Organization (WHO) believes that lessons learnt from the Ebola crisis in 2014 in 71 Africa have improved the resilience of the African healthcare systems and their capacity to test 72 and successfully impose quarantine (Fox, 2020). Countries across the continent have garnered a 73 great deal of experience from tackling infectious diseases like polio, measles, Ebola, yellow fever, 74 influenza and many more (Bruce-Lockhart, 2020). Hence, the African governments were quick to 75 impose travel bans on airlines carrying passengers from Europe at the very beginning of the 76 pandemic while Europe and North American countries went into self-imposed economic and social 
77 lockdown at a later stage. Economically, the UNECA reckons that Nigeria could suffer a $\$ 19$

78 billion hit, largely from lost oil revenues (Fox, 2020).

79 During the long lockdown in Nigeria, many economic and social activities were brought to a halt;

80 commercial activities; vehicular movements (private and governmental owned); most industrial

81 activities, especially in the oil rich cities of the Delta which account for the greater percentage of

82 emissions in Nigeria, and other human activities which invariably reduced anthropogenic

83 emissions. Air pollution (release of harmful substance to the atmosphere in a concentration that

84 could pose serious threats to humans, animals and plants) is a serious concern to the world. Air

85 quality can be affected by natural sources such as volcanic eruptions, and natural disasters, and

86 by anthropogenic sources such as the combustion of fossil fuels (diesel, gasoline, and oil) used for

87 energy production and by industrial activities related to construction, mining, cement

88 manufacturing, and smelting ( Li and Mallat,2018; Al-Thani,et al.,2018; Al-Thani et al.,2020).

89 Several studies have been carried out to assess the impacts of air pollution on humans as it poses

90 a serious health risk. For instance, the exposure to an elevated amount of $\mathrm{NO}_{2}$ has been associated

91 with hypertension illness (Shin et al., 2020). Several studies have shown an increased rate of heart-

92 related diseases due to air pollution exposure (Li et al., 2016; Logue et al., 2012). Nwachukwu et

93 al., (2012) reported on the effect of air pollution on inducing several diseases for the people living

94 in the vicinity of Rivers State in Nigeria by comparing epidemiological data to air quality data.

95 The results showed that a total of 30,435 cases of illness (e.g., pertussis, pulmonary tuberculosis,

96 cerebrospinal meningitis (CSM), pneumonia, measles, chronic bronchitis, and upper respiratory

97 tract infection (URT)) were reported between 2003 and 2008, of which 61 patients died.

98 There have been reports on the reduction of air pollution since the advent of coronavirus in various

99 cities of the world. Isaifan has initially reported on the air quality status in China before and after 
100 the coronavirus crisis (Isaifan, 2020). It has been shown that shutting down industrial activities

101 which are considered intense sources of air pollution, in response to the COVID-19 pandemic

102 emergency lockdown may have saved more lives by preventing air pollution than by preventing

103 infection with the virus. In India, Gupta et al., (2020) analyzed various environmental impacts due

104 to the lockdown as prevention for COVID-19 throughout India. They observed a significant

105 reduction in the main air pollutants such as nitrogen dioxide, carbon monoxide, sulphur dioxide,

106 ozone and particulate matter, hence the positive impact of containment of air quality. In India,

107 Sharma et al., (2020) investigated the impact of COVID-19 on restricting activities by analyzing

108 the concentrations of six criteria pollutants, $\mathrm{PM}_{10}, \mathrm{PM}_{2.5}, \mathrm{CO}, \mathrm{NO}_{2}$, ozone and $\mathrm{SO}_{2}$ during March

$10916^{\text {th }}$ to April $14^{\text {th }}$ from 2017 to 2020 in 22 cities covering different regions of India. They reported

110 an overall 43, 31, 10, and $18 \%$ decreases in $\mathrm{PM}_{2.5}, \mathrm{PM}_{10}, \mathrm{CO}$, and $\mathrm{NO}_{2}$; respectively in India during

111 lockdown period compared to previous years while, there were $17 \%$ increase in $\mathrm{O}_{3}$ and negligible

112 changes in $\mathrm{SO}_{2}$.

113 Using ground-based monitoring stations, IQAir Air Visual (2019) World air quality assessed the

114 impact of COVID-19 restrictions on $\mathrm{PM}_{2.5}$ levels for 10 major cities around the world. The

115 reduction in $\mathrm{PM}_{2.5}$ was observed in 9 of the 10 cities compared to the same period in 2019. The

116 best air quality was recorded in Wuhan in February and March 2020. Delhi air quality dropped

117 from $68 \%$ in 2019 before the lockdown period to $17 \%$ during the lockdown period, while the

118 longest period of clean air was recorded in Los Angeles in compliance with WHO air quality 119 guidelines.

120 The study reported here explored the implications of the lockdown due to COVID-19 on 121 Nigerians' air quality, and more specifically on $\mathrm{NO}_{2}$ levels. The chosen cities are Lagos, Ibadan, 122 Abuja, Kano, Owerri and Onitsha which are distributed along different locations in the country. In 
123 addition, these cities are among the top major inhabited cities in Nigeria based on their 124 demography.

\section{Lagos and Ibadan}

126 Lagos State lies in the southwestern part of Nigeria within latitudes $6^{\circ} 23^{\prime} \mathrm{N}$ and $6^{\circ} 41^{\prime} \mathrm{N}$ and 127 longitudes $2^{\circ} 42^{\prime} \mathrm{E}$ and $3^{\circ} 42^{\prime} \mathrm{E}$. Lagos is the most populous city in Nigeria and in all Africa, and 128 is considered the financial center of the metropolis. Fifty percent of Nigeria's industrial activities 129 including 300 industries in 12 industrial Estates are located in the Lagos area. The high 130 urbanization and industrial growth rate in Lagos has made it one of the most densely-populated 131 regions on earth with about 9.3 million inhabitants according to 2006 Census (Adesuyi et al,2015).

132 The city has a tropical climate with an average relative humidity of $79 \%$. The mean monthly 133 temperature ranges from $23-32^{\circ} \mathrm{C}$. Being located in a coastal area and influenced by strong sea 134 based disturbances, Lagos experiences an average wind speed of $4.3 \mathrm{~km} / \mathrm{h}$ (Komolafe et al, 2014).

135 Lagos metropolis has been experiencing air pollution problems in all its severity over the past 136 decades (Njoku et al.,2016). Sources of air pollution include traffic (vehicle exhaust), industrial 137 sectors (from brick making to oil and gas production), power plants and generating sets, cooking 138 and heating with solid fuels (e.g. coal, wood, crop waste), forest fires and open burning of 139 municipal waste and agricultural residues (Akanni ,2010; Komolafe et al.,2014).

140 Ibadan is the capital of Oyo State, South West Nigeria. Ibadan is positioned on longitude $3^{\circ} 53 \mathrm{E}$ of 141 Greenwich Meridian and latitude $7^{\circ} 23 \mathrm{~N}$ of the equator. This ancient city is located close to forest 142 and grassland boundary of south western Nigeria and about $145 \mathrm{~km}$ North East. Due to its location, 143 Ibadan serves as a meeting point for people and products from forest and grassland areas (Rowland 144 Ana, 2015). The city of Ibadan is known to be the third largest metropolitan area in Nigeria after 145 Lagos and Kano. This is because it is one of the fastest urbanizing cities in Nigeria. The increase 
146 in urbanization is attributed to the provision of better economic opportunities due to setting up of

147 factories and industries, which has led to migration of population from rural regions to the city. As

148 a result, people spread to the peripheral areas of the urban fringes (Rowland Ana, 2015).

149 Kano

150 Kano is the capital of Kano State, Nigeria which lies between latitude $11^{0} 55^{\prime} 23.93^{\prime} \mathrm{N}$ to $12^{0}$

$1513^{\prime} 53.10^{\prime} \mathrm{N}$ and longitude $8^{0} 27^{\prime} 42.26^{\prime} \mathrm{E}$ to $8^{0} 36^{\prime} 41.62^{\prime} \mathrm{E}$ and is 1549 feet above sea level. The

152 estimated area of Kano metropolis increased from 122.7 square kilometers in 1962 to 154.6 square

153 kilometers in 1981 , an increase of about $25 \%$ based on the average expansion rate of two square

154 kilometers per annum (Na'Abba, 2002).

155 Kano is referred to as the Center of Commerce in the Country due to its long flourished marketing 156 activities. This is based on the fact that marketing and trading has been the dominant economic 157 activities in Kano. However, the land is mostly exploited by urban agriculture through waste water 158 utilization to sustain daily needs. The average temperature is a bit hot, even during the cool 159 Harmattan period, the minimum temperature hardly falls below $11^{\circ} \mathrm{C}$, whilst the monthly average 160 temperature is not less than $20^{\circ} \mathrm{C}$. During the hot season, usually Mid - March to Mid-May, the 161 maximum temperature reading can reach as high as $40^{\circ} \mathrm{C}$. The average temperature for these hot 162 months may range between $30^{\circ} \mathrm{C}$ and $32^{\circ} \mathrm{C}$ (Adzandeh et al., 2014).

163 Abuja

164 Abuja is the federal capital of Nigeria and is located at $6^{\circ} 45^{\prime \prime}$ longitude and $7^{\circ} 45^{\prime \prime} \mathrm{E}$ from 165 Greenwich and at $8^{\circ} 25^{\prime \prime}$ latitude and $9^{\circ} 25^{\prime \prime} \mathrm{N}$ from the equator. It is bounded on the north by 166 Kaduna State, on the east by Nassarawa State, on the west by Niger State and on the south by Kogi 167 State. The topography of the region is characterized by the presence of several peaks which 168 constitute the highest part of the region; located at $760 \mathrm{~m}$ above sea level (Balogun, 2001). 
169 Climatically, the region has a high intensity of precipitation which reaches $1,631.7 \mathrm{~mm}$ per year

170 and an average annual temperature between $25.8^{\circ} \mathrm{C}$ and $30.2^{\circ} \mathrm{C}$. Abuja has an international airport

171 and is linked to other Nigerian cities by a network of highways.

\section{Owerri and Onitsha}

173 Owerri is the capital of Imo State, located in south-eastern Nigeria. It is bounded on the south by

174 Nekede, on the north by Amakohia, on the east by Egbu, on the northeast by Uratta, on the 175 southeast by Naze, and on the northwest by Irette. The main activities of the inhabitants are public 176 functions, commerce and agriculture (Obionu, 2007). The average temperature is around $27^{\circ} \mathrm{C}$ 177 ((Obionu, 2004). The vegetation is typically tropical rainforest with some parts of Guinean 178 savannah as a result of environmental degradation through pollution.

179 The city of Onitsha is located on a vast flood plain on an altitude of $26 \mathrm{~m}$ above sea level between 180 latitudes $6^{\circ} 5^{\prime}$ to $6^{\circ} 11^{\prime} \mathrm{N}$ and longitudes $6^{\circ} 45^{\prime}$ to $6^{\circ} 53^{\prime} \mathrm{E}$. The climate type is equatorial tropical with 181 dry and wet seasons. The rainy season extends from March to October and the dry season begins 182 from November to February. The region is located in the rainforest belt, with an average rainfall 183 of $2100 \mathrm{~mm}$. According to the World Bank, Onitsha is the most polluted city in the world for air 184 quality as measured by the concentration of small particles $\left(\mathrm{PM}_{10}\right)$. The main factors contributing 185 to air pollution are waste combustion, emissions from old cars and the heavy use of fossil fuels for 186 cooking $(\mathrm{WHO}, 2016)$.

187 The combustion of fossil fuels in these selected cities generates large quantities of nitrogen dioxide $188\left(\mathrm{NO}_{2}\right)$, but traffic is considered the main source. $\mathrm{NO}_{2}$ causes cellular inflammation, bronchial 189 hyper-reactivity and respiratory problems, reportedly causing the death of about 4.6 million people 190 each year (Muhammad et al., 2020; Latza et al., 2009). To investigate the air quality impact of the 191 lockdown due to COVID-19, each city's tropospheric column of nitrogen dioxide was analyzed. 
192 This study compares the levels of $\mathrm{NO}_{2}$ density before the advents of the first reported case of

193 COVID-19 in Nigeria and its levels during the lockdown in selected cities to assess its impact on 194 the air quality of Nigeria.

195

196

197

198

199

200

201

202 203

204 205 206

207

208 209

210

211

212

213

\section{Materials \& Methods}

For $\mathrm{NO}_{2}$ concentration in the troposphere (from surface up to $\sim 10 \mathrm{~km}$ ), the Sentinel-5 Precursor space-borne satellite (spatial resolution of $5.5 \mathrm{~km}$ ) was used which is operated and managed by the European Commission under the "Copernicus" program. The satellite operates in a sunsynchronous orbit at $824 \mathrm{~km}$ and an orbital cycle of 16 days. The satellite carries a TROPOspheric Monitoring Instrument (TROPOMI) which provides a (near-) global coverage of air pollution caused by $\mathrm{NO}_{2}$ and other pollutants such as $\mathrm{O}_{3}, \mathrm{SO}_{2}, \mathrm{CO}, \mathrm{CH}$, and aerosols. (Veefkind et al., 2012).

This study necessitated the extraction of $\mathrm{NO}_{2}$ data from Sentinel 5P Near Real Time level 2 satellite images achieved in NetCDF format and captured for specific exposure durations in 2 separate months (December 2019 and April 2020). From the sentinel 5P satellite images, the extracted $\mathrm{NO}_{2}$ data were used to compare the trend of $\mathrm{NO}_{2}$ spread in the atmosphere before and during the COVID-19 lockdown in the Nigerian cities selected (Lagos, Owerri and Onitsha, Abuja and Kano).

The Panoply 4.11.2 application was used to process the Network Common Data Format files (NetCDF) to raster images using two dimensions latitude and longitude (in that order) and scaled to reflect the proper $\mathrm{NO}_{2}$ concentration, ArcMap 10.5 was used to analyze the $\mathrm{NO}_{2}$ sentinel $5 \mathrm{P}$ satellite images, projecting then to the scale of the selected cities, likewise, applying standard 
214 deviation stretch to address the image stretch property as a result of the analysis carried out on the 215 images.

216 For the secondary data which includes Sentinel 5P NO 2 Satellite imagery (Table 1) covering the 217 study area in NetCDF file format were obtained from Copernicus website and the Tropospheric 218 column of Nitrogen dioxide file for the months of April and December was used in this research 219 work.

220 In addition, administrative boundaries (National and State boundary shape files) of Nigeria was 221 sourced from DIVA-GIS website a repository of free spatial data. The resultant image provided 222 information on $\mathrm{NO}_{2}$ concentrations within the study areas. The maps were scaled to 1:60,000.

223 Additional secondary data were also obtained from a number of literatures ranging from text 224 books, research articles and journal papers. Table 1 shows the various data types used in this 225 research and their sources.

226 Sentinel 5P Near Real Time Level 2 images for the months of December 2019 and April 2020 for 227 the study area, were plotted in Panoply. The tropospheric vertical column of nitrogen dioxide of 228 each NetCDF file was plotted using the georeferenced longitude and latitude color contour plot. 229 Using the scalar unit of micromole per meter square with a scale range minimum of 0 and 230 maximum of 100, the plotted images were later exported to tagged image file format for further 231 analysis in ArcMap.

232 The Tagged Image file (TIF) plotted in Panoply environment was processed in ArcMap, the image 233 was georeferenced and projected to UTM 31; clipped using the Nigeria National Boundary; 234 overlaid with the State boundary and State capitals.

\section{Results}


236 Figure 1 shows the map of Nigeria and highlights the areas included in this study. Table 2 shows

237 the main features of the cities chosen for this study. Figure 2 shows the demographic distribution

238 of confirmed cases in Nigeria. It can be seen that highly dense and populated areas have witnessed

239 more infections than other regions as expected. Moreover, the demographic distribution of infected

240 cases show that male confirmed cases were dominant over female's with 9117 cases for male and

2414347 female which accounted to $68 \%$ and 32\%; respectively (Table 3 and Figure 3). Moreover,

242 Fig. 3 reveals that the most affected age group is $31-40$ which makes up about $24 \%$ of all age-

243 group cases.

244 Table 4 shows the total registered cases with COVID-19 globally and the new cases in the last 24

245 hours as per the $10^{\text {th }}$ of June, 2020. It can be seen that Africa has the least number of cases with

$2462.03 \%$ out of all registered cases globally. The same can be seen from the number of deaths which

247 amounted to $0.86 \%$ of global deaths by COVID-19. Moreover, Fig. 4 shows the epidemic curve

248 of confirmed cases in Nigeria. In addition, figures in Table 5 shows Situation updates in numbers

249 with the total cases (new cases in the last 24 hours) by June $10^{\text {th }}, 2020$.

250

251 From the analysis of the map in Fig. 5 (B), it can be seen that nitrogen dioxide pollution has been 252 widely present around the city of Lagos and its surroundings with high concentrations reaching $253156.9 \mu \mathrm{mol} / \mathrm{m}^{2}$ and above $575.7 \mu \mathrm{mol} / \mathrm{m}^{2}$, with Ikeja the capital of the city recording 505.9305 $254 \mu \mathrm{mol} / \mathrm{m}^{2}$. Oyo State generally has a much lower nitrogen dioxide emissions between -52.36 $255 \mu \mathrm{mol} / \mathrm{m}^{2}$ to $471 \mu \mathrm{mol} / \mathrm{m}^{2}$ compared to Lagos state, while Ibadan town has a concentration of $256453.58 \mu \mathrm{mol} / \mathrm{m}^{2}$ at the time before lockdown. Nevertheless, the map representing lockdown period 257 (Fig. 5 A) shows a visible decrease in nitrogen dioxide concentrations, with Ikeja measuring a 258 negative value of $-60.41 \mu \mathrm{mol} / \mathrm{m}^{2}$ representing a decrease in Nitrogen dioxide concentration. Lagos 
259 overall concentration is between $-95.15 \mu \mathrm{mol} / \mathrm{m}^{2}$ and $-25.05 \mu \mathrm{mol} / \mathrm{m}^{2}$. This indicated significant 260 decrease in activities that generate $\mathrm{NO}_{2}$ due to lockdown restrictions.

261 The distribution of nitrogen pollution in the city of Kano is less severe compared to Lagos, only 262 Kano town and its vicinity recorded a high concentration range between $471.03 \mu \mathrm{mol} / \mathrm{m}^{2}$ and $263366.34 \mu \mathrm{mol} / \mathrm{m}^{2}$ while the rest have recorded values between $-50.46 \mu \mathrm{mol} / \mathrm{m}^{2}$ and $191.84 \mu \mathrm{mol} / \mathrm{m}^{2}$ 264 before lockdown as shown in Fig. 6 (B) which is representative of December 2019. Whereas, 265 during the containment period April 2020 (Fig. 6 A), $\mathrm{NO}_{2}$ pollution has reduced drastically in the 266 entire Kano area, with values ranging between $-49.59 \mu \mathrm{mol} / \mathrm{m}^{2}$ to $55.70 \mu \mathrm{mol} / \mathrm{m}^{2}$ while Kano town 267 records values at about $-37.47 \mu \mathrm{mol} / \mathrm{m}^{2}$.

268 Figure 7 (B) shows that $\mathrm{NO}_{2}$ has high concentrations in the city of Abuja and in the north of the 269 city with the presence of several spots with high $\mathrm{NO}_{2}$ concentrations during December 2019.Abuja 270 city and northwest of Abuja city area show $\mathrm{NO}_{2}$ concentration values ranging between 296.54 $271 \mu \mathrm{mol} / \mathrm{m}^{2}$ to $575.73 \mu \mathrm{mol} / \mathrm{m}^{2}$. Other neighbouring towns southward Abuja marked values between $27217.35 \mu \mathrm{mol} / \mathrm{m}^{2}$ to $157 \mu \mathrm{mol} / \mathrm{m}^{2}$. On the other hand, the results in Fig. (7 A) do not show any spots 273 with $\mathrm{NO}_{2}$ pollution due to lockdown measures, therefore accounting for a low $\mathrm{NO}_{2}$ reading 274 between $-3.53 \mu \mathrm{mol} / \mathrm{m}^{2}$ and $33.19 \mu \mathrm{mol} / \mathrm{m}^{2}$ within the Federal Capital Territory, while Abuja 275 Town accounts for readings around $26.23 \mu \mathrm{mol} / \mathrm{m}^{2}$.

276 Based on the analysis of the results presented in Figure 8, it is found that Onitsha area is the most 277 polluted with the presence of several scattered spots representing $\mathrm{NO}_{2}$ pollution throughout the 278 region (Fig. 8 B). The atmosphere in Onitsha town is charged with about $296.5 \mu \mathrm{mol} / \mathrm{m}^{2}$ while 279 Owerri town measures $471.03 \mu \mathrm{mol} / \mathrm{m}^{2}$, other places measure as high as $156.9 \mu \mathrm{mol} / \mathrm{m}^{2}$. Fig. $(8$ 280 A) shows a significant drop in $\mathrm{NO}_{2}$ concentrations during the lockdown period. Onitsha records 
$28115.94 \mu \mathrm{mol} / \mathrm{m}^{2}(94 \%)$ reduction while other places within the state measure $35.01 \mu \mathrm{mol} / \mathrm{m}^{2}$ (highest 282 within the state) while Owerri town records $38.11 \mu \mathrm{mol} / \mathrm{m}^{2}$, with lowest value of $-18.17 \mu \mathrm{mol} / \mathrm{m}^{2}$ 283 and highest value of $60.29 \mu \mathrm{mol} / \mathrm{m}^{2}$ within Anambra state. It is noted that the pollution have fallen 284 further in the area with the persistence of a few spots with high $\mathrm{NO}_{2}$ concentrations, which is 285 normal since this city is one of the most polluted in terms of air pollution in the world.

\section{Discussion}

287 COVID-19 is a major pandemic and global issue that caused severe health, social and economic 288 impacts in every country. Nevertheless, Africa has been reported to have had less impact due to 289 its early measures taken to abate this disease due to its recent experiences in similar infectious 290 disease over the past decades.

291 This study analyzed the impact of COVID-19 on $\mathrm{NO}_{2}$ concentration in six major cities in Nigeria; 292 namely: Lagos, Ibadan, Kano, Abuja, Owerri and Onitsha. To understand the impacts of the 293 lockdown conditions, Sentinel 5P Near Real Time level 2 Nitrogen dioxide $\left(\mathrm{NO}_{2}\right)$ satellite images 294 extracted for specific durations in 2 separate months (December, 2019 and April, 2020) as shown in Figures 5-8. The results show significant reduction in $\mathrm{NO}_{2}$ concentrations over the cities under investigation due to the lockdown measures taken by the government. These reductions in $\mathrm{NO}_{2}$ could be due to restrictions on sources of anthropogenic activities such as transportation and commercial activities. Moreover, the observations related to the dramatic reduction in air polluting emissions in Nigeria are in agreement with what has been reported for other regions globally. It is worth noting that $\mathrm{NO}_{2}$ emissions can be affected by seasonality. However, more data is required to cover the same periods to avoid the influence of seasonality changes between winter and spring.

302 Recently, Fuwape, et al., (2020) recently assessed the impact of COVID-19 lockdown on air quality in three locations within Nigeria; in doing these, they compared historical air pollution 
304 (2005-2019) and air pollution during COVID-19 lockdown (especially for the months of January 305 to April, 2020) to determine the level of air quality change using boxplots. Their results revealed 306 a reduction of 1.1, 3.0, and 21.8\% change in $\mathrm{NO}_{2}$ levels for Lagos, Kaduna and Port Harcourt; 307 respectively during the period of the lockdown. In addition Lagos and Kaduna saw an increase of 30854 and $10 \%$ in $\mathrm{SO}_{2}$ levels respectively during the same period. There was also a reduction of $\mathrm{SO}_{2}$ 309 levels by $37 \%$ in Port Harcourt during the lockdown period. They attributed this differences 310 between 2005-2019 (before lockdown period) and January to April, 2020 (during lockdown 311 period) to be due to different levels of enforcement of the lockdown in the different study locations.

312 Further detailed maps of $\mathrm{NO}_{2}$ levels in Wuhan, China from the $1^{\text {st }}$ of January through the $25^{\text {th }}$ of

313 February of last year (2019) show the region covered with intense dark layers indicating much 314 higher concentrations of $\mathrm{NO}_{2}$. The images were compared with the same period in 2020 after the 315 breakout of coronavirus where reduced levels of $\mathrm{NO}_{2}$ have been observed (Isaifan, 2020).

316 Recently, Bashir et al., (2020) studied the correlation between the fast spread of COVID-19 and 317 the climate indicators such as temperature and humidity in New York City in USA (Bashir et 318 al.,2020). They found a correlation between the minimum and average temperatures with the 319 spread of COVID-19 indicating that higher temperature serves as a driver for the COVID-19. 320 Moreover, humidity was found to be another factor for the spread of COVID-19 as it contributed 321 towards the rapid transmission of COVID-19 within New York City. In addition, the population 322 density ( 8.54 million people, 26,403 people per square mile) and being a cultural and financial 323 capital of the world, New York City experiences large amount of global travel all of which plays 324 a role in rapid transmission of Covid-19 (Bashir et al.,2020). Similarly, the higher densely 325 populated cities in Nigeria such as Lagos had extremely higher levels of pollution, and hence more 326 confirmed cases and deaths are expected. 


\section{Conclusions}

328 In this study, the variation of $\mathrm{NO}_{2}$ which was collected from the satellite (Sentinel $-5 \mathrm{P}$ ) was used

329 to indicate the significant reduction in the level of $\mathrm{NO}_{2}$ in six major cities in Nigeria. The 330 observations compare the level of $\mathrm{NO}_{2}$ emissions before and after lockdowns. Two main durations 331 were compared (December, 2019 and April, 2020). $\mathrm{NO}_{2}$ emission in the various cities under study 332 shows a significant drop after the first coronavirus was announced in Nigeria, this could be due to 333 restriction of vehicular and commercial activities as also reported in various cities across the world.

334 There could be an element of uncertainty in the results due to seasonality, as the comparison is 335 done with a different season. However, the magnitude of change due to lockdown is probably 336 much higher than the seasonal variability. The outcomes indicated that the novel coronavirus is 337 considered a blessing in disguise. The current status of air quality in terms of lower $\mathrm{NO}_{2}$ 338 concentrations has significantly improved. The impact might be temporary but there is a very good 339 opportunity for all nations to learn about the outcomes of lockdown with minimum impact on 340 economy.

342 Table Captions

343 Table 1. Data type and sources of data collected for this research.

344 Table 2. Population, area, and population density in each of the cities included in this work as 345 per Worldometer census data.

346 Table 3. Demography and most affected age group by June $10^{\text {th }}, 2020$.

347 Table 4. Situation in numbers by WHO Region. Total positive cases (new cases in the last $24 \mathrm{~h}$ ), 348 and total deaths (new cases in the last $24 \mathrm{~h}$ ) by June $10^{\text {th }}, 2020$. 
349 Table 5. Situation updates in numbers. Total positive cases (new cases in the last 24 hours) by

350 June $10^{\text {th }}, 2020$.

351

352 Figure Captions

353 Figure 1. Map showing Nigeria and areas included in this study.

354 Figure 2. COVID-19 outbreak status in Nigeria. Number of positive cases.

355 Source: Nigerian Centre for Diseases Control (NCDC) data as at June $10^{\text {th }}, 2020$

356 Figure 3. Age-Sex distribution of confirmed cases.

357 Source: Nigeria Centre for Disease Control (NCDC) 2020

358 Figure 4. Daily epidemic curve of confirmed cases.

359 Source: Nigeria Centre for Disease Control (NCDC) 2020.

360 Figure 5. Nitrogen dioxide concentration levels over Lagos and Ibadan during lockdown period

361 April, 10-18, 2020 (A) and pre-lockdown period Dec., 10-14, 2019 (B).

362 Figure 6. Nitrogen dioxide concentration levels over Kano during lockdown period April, 10-

363 18, 2020 (A) and pre-lockdown period Dec., 10-14, 2019 (B).

364 Figure 7. Nitrogen dioxide concentration levels over Abuja during lockdown period April, 10-

365 18, 2020 (A) and pre-lockdown period Dec., 10-14, 2019 (B).

366 Figure 8. Nitrogen dioxide concentration levels over Owerri and Onitsha during lockdown

367 period April, 10-18, 2020 (A) and pre-lockdown period Dec., 10-14, 2019 (B).

\section{Acknowledgements}

369 We appreciate the World Health Organization (WHO) and the Nigerian Centre for Disease

370 Control (NCDC) for granting us the opportunity to use some of its publications 
377 References

378

379

380

381

382

383

384

385

386

387

388

389

390

391

392

393

394

Adesuyi A, Njoku K,Akinola M.2015. Assessment of Heavy Metals Pollution in Soils and Vegetation around Selected Industries in Lagos State, Nigeria, J. Geosci. Environ. Prot., vol. 9, pp. 11-19.

Adzandeh E,Fabiyi O,Bello Y .2014. Statistical Analysis of Urban Growth in Kano Metropolis, Nigeria, Int. J. Environ. Monit. Anal., vol. 2, pp. 50-56.

Akanni C.2010. Spatial and seasonal analysis of traffic-related pollutant concentrations in Lagos Metropolis, Nigeria,African J. Agric. Res., vol. 5, pp. 1264-1272.

Al-Thani H, Koç M, Isaifan RJ.2018.A review on the direct effect of particulate atmospheric pollution on materials and its mitigation for sustainable cities and societies, Environ. Sci. Pollut. Res., vol. 25, no. 28, pp. 27839-27857.

Al-Thani H, Koç M,Fountoukis C,Isaifan RJ.2020.Evaluation of particulate matter emissions from non-passenger diesel vehicles in Qatar,J. Air Waste Manage. Assoc., vol. 70, no. 2, pp. $228-242$

Balogun O. 2000.The Federal Capital Territory of Nigeria: a geography of its development, Ibadan. Ibadan University Press.

Bashir MF et al.2020.Correlation between climate indicators and COVID-19 pandemic in New York, USA,” Sci. Total Environ., vol. 728, p. 138835. 
395 Bruce-Lockhart A.2020. Africa-least affected by COVID," World Economic Forum. [Online].

396

397

398

399

400

401

402

403

404

405

406

407

408

409

410

411

412

413

414

415

416

417
Available: https://www.weforum.org/agenda/2020/05/covid19-africa-

hydroxycholoroquine-world-health-organization/.

Fox B.2020. The last continent to face up COVID-19, Africa 'needs to wake up,"Euractive.

[Online]. Available: https://www.euractiv.com/section/botswana/news/the-last-continent-

to-face-up-covid-19-africa-needs-to-wake-up/.

Fuwape IA, Okpalaonwuka CT, Ogunjo ST.2020. Impact of COVID -19 pandemic lockdown on distribution of inorganic pollutants in selected cities of Nigeria. Air Qual Atmos

Health. 1-7. doi:10.1007/s11869-020-00921-8

Gupta N, Tomar A, Kumar V.2020. The effect of COVID-19 lockdown on the air environment in India," Glob. J. Environ. Sci. Manag., vol. 6, pp. 31-40.

Isaifan,RJ.2020. The dramatic impact of coronavirus outbreak on air quality: Has it saved as much as it has killed so far?," Glob. J. Environ. Sci. Manag., vol. 6, no. 3, pp. 275-288,

Kalu B.2020 .COVID-19 in Nigeria: A disease of hunger," The Lancet, 2020. [Online]. Available: www.thelancet.com/respiratory Vol 8

Komolafe A,Adegboyega S, Anifowose A, Akinluyi F, Awoniran D.2014. Air Pollution and Climate Change in Lagos, Nigeria: Needs for Proactive Approaches to Risk Management and Adaptation. , 10 (4): Am. J. Environ. Sci., pp. 412-423.

Latza U, Gerdes S, Baur X. 2009. Effects of Nitrogen dioxide on human health; Systematic review of experimental and epidemiological studies conducted between 2002 and 2006," Int. J. Hyg. Environ. Health, vol. 212, pp. 271-287.

Lawal A. 2004.Composition and Special Distribution, Solid Waste Collection Points in Urban Katsina, Northern Nigeria, Environmentalist, vol. 24, pp. 62-64

Peer] reviewing PDF | (2020:09:52473:3:0:NEW 5 Apr 2021) 
418 Li M, Mallat L.2018. Health impacts of air pollution," in The Art \& Science of Risk, p. 42.

419 Li Y,Henze DK, Jack D, Henderson BH,Kinney PL.2016. Assessing public health burden

420

421

422

423

424

425

426

427

428

429

430

431

432

433

434

435

436

437

438

439

associated with exposure to ambient black carbon in the United States, Sci. Total Environ., vol. 539, pp. 515-525

Logue JM, Price PN, Sherman MH ,Singer BC.2012.A Method to Estimate the Chronic Health Impact of Air Pollutants, Environ. Health Perspect., vol. 120, no. 2, pp. 216-222.

Muhammad S,Long X, Salman M. 2020. Covid-19 pandemic and environmental pollution: A blessing in disguise? Sci. Total Environ., vol. 728, p. 138820.

Na'Abba I. 2002. Transformation of the Kabuga Housing Estate," Department of Geography. B.U.K

Njoku KL, Rumide TJ ,Akinola AO, Adesuyi AA, Jolaoso AO. 2016. Ambient Air Quality Monitoring in Metropolitan City of Lagos, Nigeria,J. Appl. Sci. Environ. Manag., vol. 20, no. 1, p. 178

Nwachukwu A,Chukwuocha, Igbudu EO. 2012.A survey on the effects of air pollution on diseases of the people of Rivers State, Nigeria, African J. Environ. Sci. Technol., vol. 6, pp. 371-379.

Obionu C.2007.Primary Health Care for Developing Countries, 2nd Editio. University of Nigerian Enugu Campus, Enugu.

Owoeye J, Ogundiran A.2015.A study on housing and environmental quality of Moniya community in Ibadan, Nigeria," Int. J. Phys. Hum. Geogr., vol. 3, pp. 31-45.

Peiris J, Guan Y,Yuen K. 2004.Severe acute respiratory syndrome," Nat. Med., vol. 10, pp. S88-S97 
440 Rowland Ana G.2015. Spatio-Temporal Variations in Carbon Monoxide and Carbon Dioxide

441 Levels in Tree Motor Parks in Ibadan, Nigeria, Int. J. Environ. Monit. Anal., vol. 3, p. 411.

442 Shin S, Bai L, Oiamo T,Al E.2020. Association Between Road Traffic Noise and Incidence of

443 Diabetes Mellitus and Hypertension in Toronto, Canada: A Population-Based Cohort

444 Study, J. Am. Hear. Assoc., vol. 9, p. e013021

445 Veefkind JP,Aben I,McMullan K, Förster H,deVries J,Otter G,Claas J,Eskes HJ,de Haan

446 JF, Kleipool Q ,etal 2012. TROPOMI on the ESA Sentinel-5 Precursor: a GMES mission

447 for global observations of the atmospheric composition for climate, air quality and ozone

448 layer applications. Remote Sens. Environ.,vol 120, pp 70-83.

449 World Health Organization.2016. Urban Ambient Air Pollution database update.

450 Sharma S, Zhang M, Anshika, Gao J,Zhang H,Kota SH.2020. Effect of restricted emissions

451 during COVID-19 on air quality in India," Sci. Total Environ., vol. 728, p. 138878.

452 Zaki A, van Boheemen S, Bestebroer T, Osterhaus A, Fouchier R .2012. Isolation of a novel

453 coronavirus from a man with pneumonia in Saudi Arabia, N. Engl. J. Med., vol. 367, pp.

$454 \quad 1814-1820$.

455 Zhoua D, Zhang P, Bao C,Zhang Y, Zhu, N.2020.Emerging Understanding of Etiology and

456 Epidemiology of the Novel Coronavirus (COVID-19) infection in Wuhan, China Daibing

457 Zhou," Preprint, no. February, pp. 1-12.

458

459

460

461

462

Peer] reviewing PDF | (2020:09:52473:3:0:NEW 5 Apr 2021) 


\section{Table $\mathbf{1}$ (on next page)}

Data type and sources of data collected for this research. 
2 Table 1. Data type and sources of data collected for this research.

\begin{tabular}{llllll}
\hline No. & Name Type & Data Source & Date Acquired & File Name & $\begin{array}{c}\text { Filename } \\
\text { Extension }\end{array}$ \\
\hline 1 & $\begin{array}{l}\text { Nitrogen } \\
\text { dioxide } \\
\text { tropospheric } \\
\text { column }\end{array}$ & $\begin{array}{l}\text { http://s5phub.cope } \\
\text { rnicus.eu/dhus/\#/h } \\
\text { ome }\end{array}$ & $\begin{array}{l}\text { April 2019, } \\
\text { December } \\
2019, \text { April }\end{array}$ & NetCDF & .nc \\
& & 2020 & & \\
\hline 2 & National & http://diva- & March, 2020 & Shape file & .shp \\
& $\begin{array}{l}\text { and State } \\
\text { Boundary }\end{array}$ & gis.org/data & & (Polygon) & \\
\hline 3 & State & Google Earth Pro & March, 2020 & Keyhole Markup & Kmz /Kml \\
& Capital & & & Language Zipped & \\
\hline
\end{tabular}

3

4 


\section{Table 2 (on next page)}

Population, area, and population density in each of the cities included in this work as per Worldometer census data. 
1 Table 2. Population, area, and population density in each of the cities included in this work as

2 per Worldometer census data.

\begin{tabular}{cccc}
\hline City & $\begin{array}{c}\text { Population } \\
(\mathbf{2 0 2 0})\end{array}$ & $\begin{array}{c}\text { Area } \\
\left(\mathbf{K m}^{\mathbf{2}}\right)\end{array}$ & $\begin{array}{c}\text { Population density } \\
\left(\mathbf{p e r s o n} / \mathbf{K m}^{\mathbf{2}}\right)\end{array}$ \\
\hline Lagos & $9,000,000$ & 1,171 & 7,685 \\
\hline Kano & $3,626,068$ & 449 & 8,076 \\
\hline Ibadan & $3,565,108$ & 3,080 & 1,158 \\
\hline Abuja & 590,000 & 1,769 & 334 \\
\hline Owerri & 215,038 & 551 & 390 \\
\hline Onitsha & 561,066 & 52 & 10,789 \\
\hline
\end{tabular}

3 
Table 3 (on next page)

Demography and most affected age group by June $10^{\text {th }}, 2020$. 
1

2

3

5

6
Table 3. Demography and most affected age group by June $10^{\text {th }}, 2020$.

\begin{tabular}{|c|c|c|}
\hline \multicolumn{2}{|c|}{ Demography } & Most affected age group \\
\hline Male & Female & $31-40$ \\
\hline $9117(68 \%)$ & $4347(32 \%)$ & $(24 \%)$ \\
\hline
\end{tabular}




\section{Table 4 (on next page)}

Situation in numbers by WHO Region. Total positive cases (new cases in the last $24 \mathrm{~h}$ ), and total deaths (new cases in the last $24 \mathrm{~h}$ ) by June $10^{\text {th }}, 2020$. 
1

2 Table 4. Situation in numbers by WHO Region. Total positive cases (new cases in the last $24 \mathrm{~h}$ ), 3 and total deaths (new cases in the last $24 \mathrm{~h}$ ) by June $10^{\text {th }}, 2020$.

4

\begin{tabular}{lllll}
\hline Globally & $\mathbf{7 1 4 5 5 3 9}$ & cases (105621) & $\mathbf{4 0 8 0 2 5}$ & deaths (3629) \\
\hline Africa & 145287 & cases $(4789)$ & 3493 & deaths $(141)$ \\
\hline Americas & 3415174 & cases $(48923)$ & 185863 & deaths $(1913)$ \\
\hline Eastern Mediterranean & 677338 & cases $(18724)$ & 15246 & deaths (333) \\
\hline Europe & 2321147 & cases $(17786)$ & 185537 & deaths (866) \\
\hline South-East Asia & 392674 & cases $(14556)$ & 10741 & deaths (365) \\
\hline Western Pacific & 193178 & cases $(843)$ & 7132 & deaths $(7132)$
\end{tabular}

5 Source: Situation Report-142 Data as reported by WHO from National Authorities by 10:00 CEST, by

6 June $10^{\text {th }}, 2020$ 


\section{Table 5 (on next page)}

Situation updates in numbers. Total positive cases (new cases in the last 24 hours) by June $10^{\text {th }}, 2020$. 
1

2

3

4

\begin{tabular}{ccccc}
\hline $\begin{array}{c}\text { Sample } \\
\text { tested }\end{array}$ & $\begin{array}{c}\text { Confirmed } \\
\text { cases }\end{array}$ & $\begin{array}{c}\text { Affected } \\
\text { States }\end{array}$ & $\begin{array}{c}\text { Discharged } \\
\text { cases }\end{array}$ & $\begin{array}{c}\text { Confirmed } \\
\text { Fatalities }\end{array}$ \\
\hline $82935(2987)$ & $13464(663)$ & $36(0)$ & $4206(166)$ & $365(4) 3 \%$ CFR \\
\hline
\end{tabular}

Table 5. Situation updates in numbers. Total positive cases (new cases in the last 24 hours) by June $10^{\text {th }}, 2020$.

5 
Figure 1

Map showing Nigeria and areas that have been included in this study.

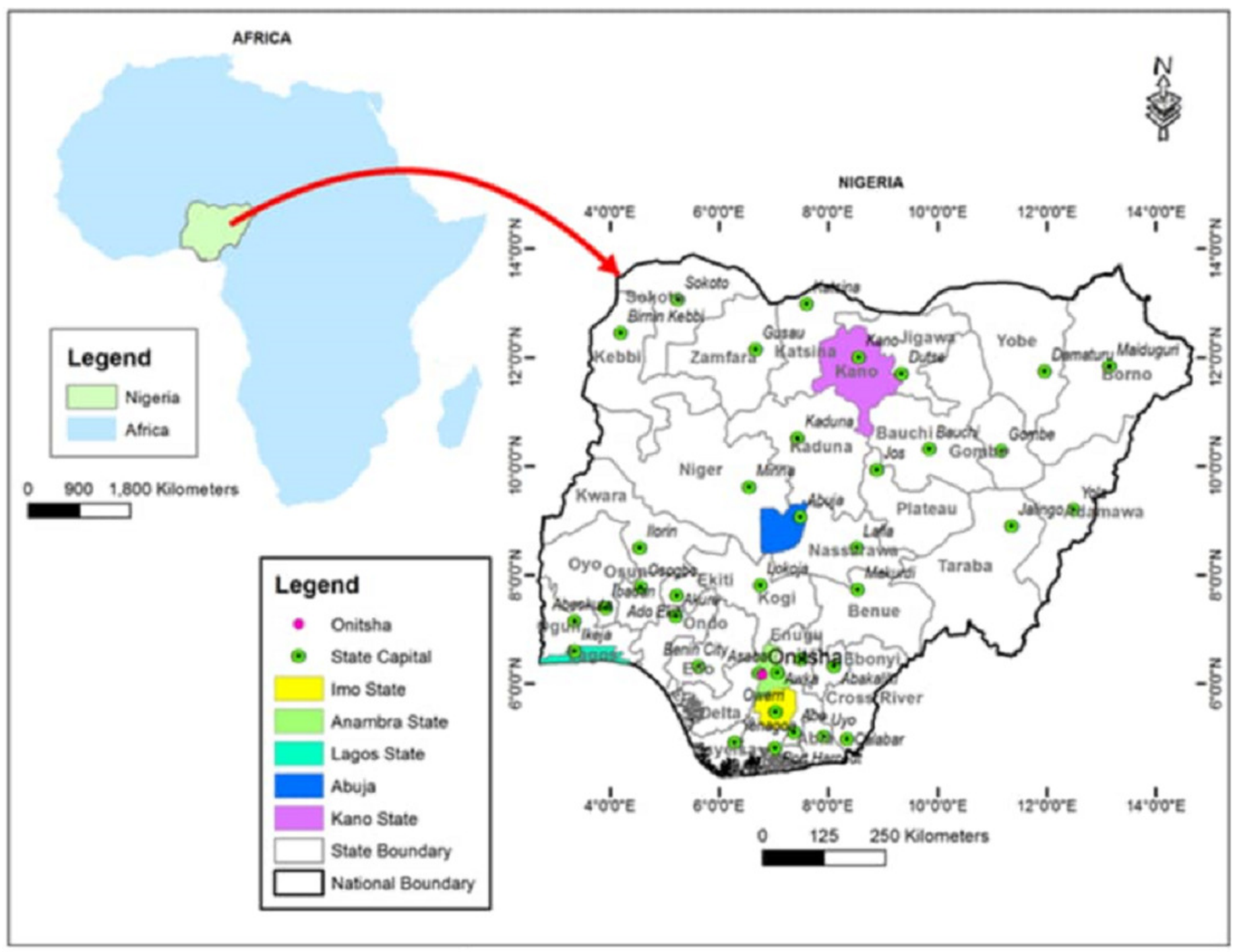

Source: DIVA-GIS;http://www.diva-gis.org/Data 
Figure 2

COVID-19 outbreak status in Nigeria. Source: Nigerian Centre for Diseases Control (NCDC) data as of June $10^{\text {th }}, 2020$.

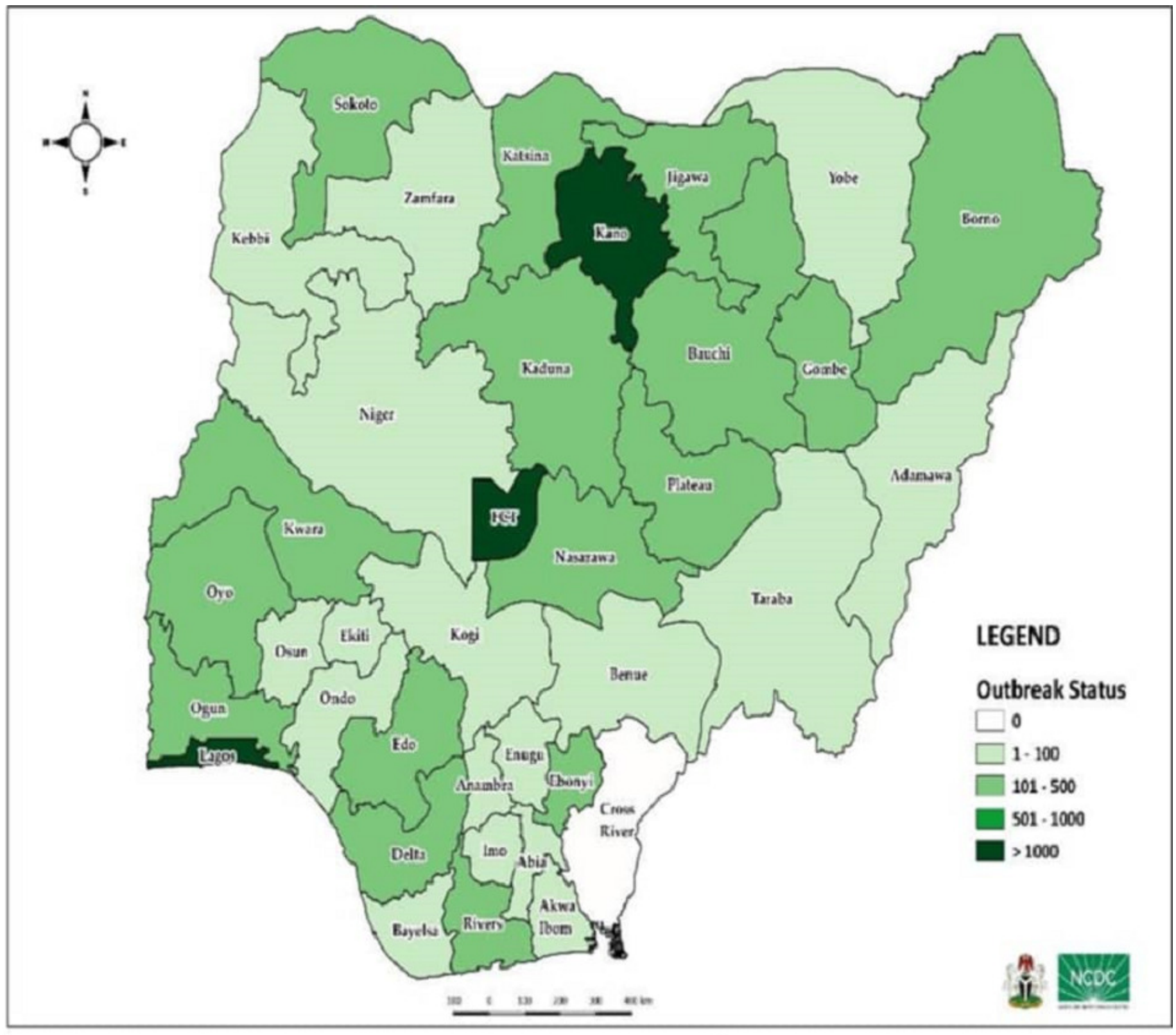

Source: Nigeria Centre for Disease Control (NCDC) 2020. 
Figure 3

Age-Sex distribution of confirmed cases.

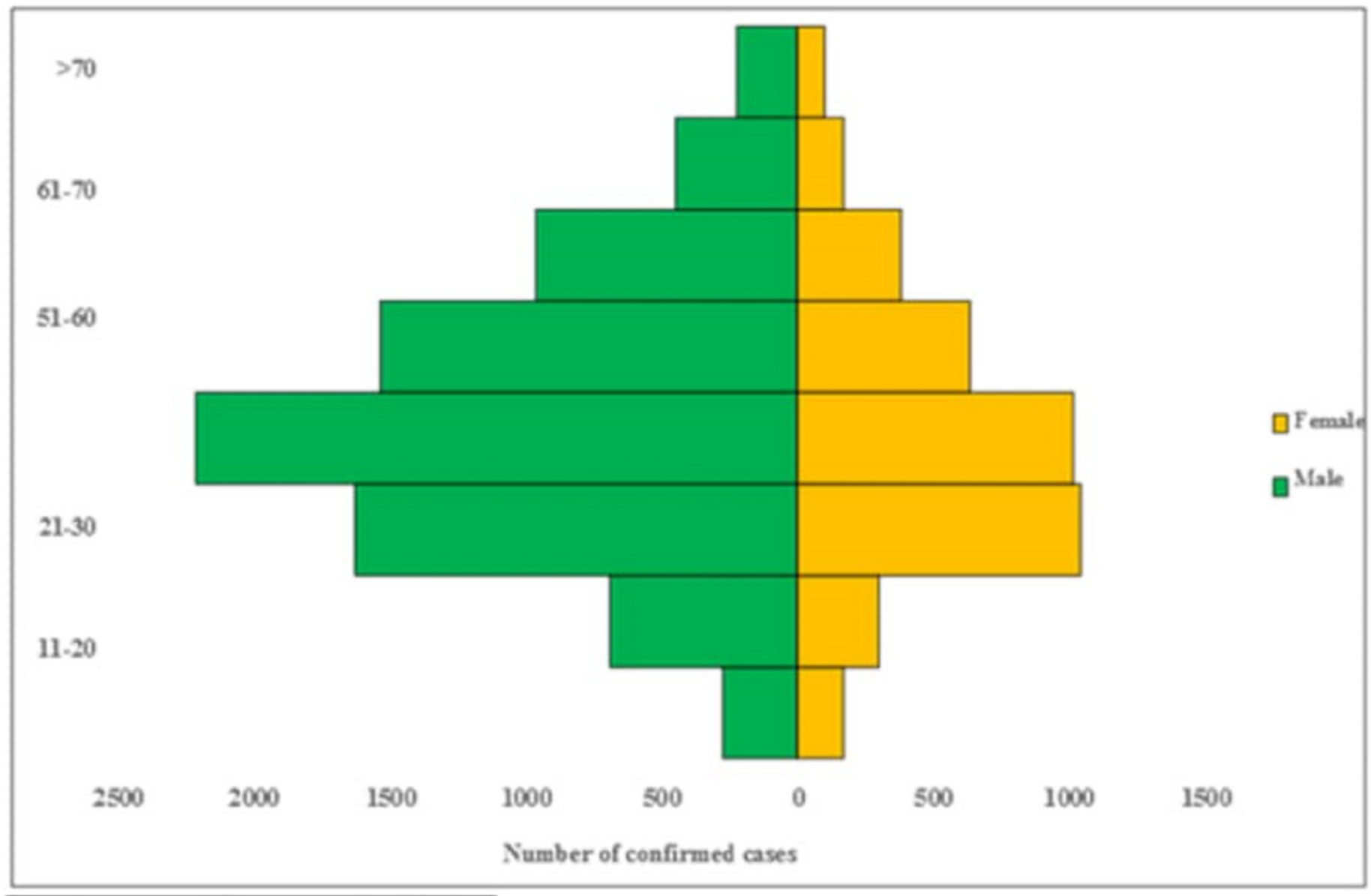

Source: Nigeria Centre for Discase Control (NCDC) 2020. 
Figure 4

Daily epidemic curve of confirmed cases.

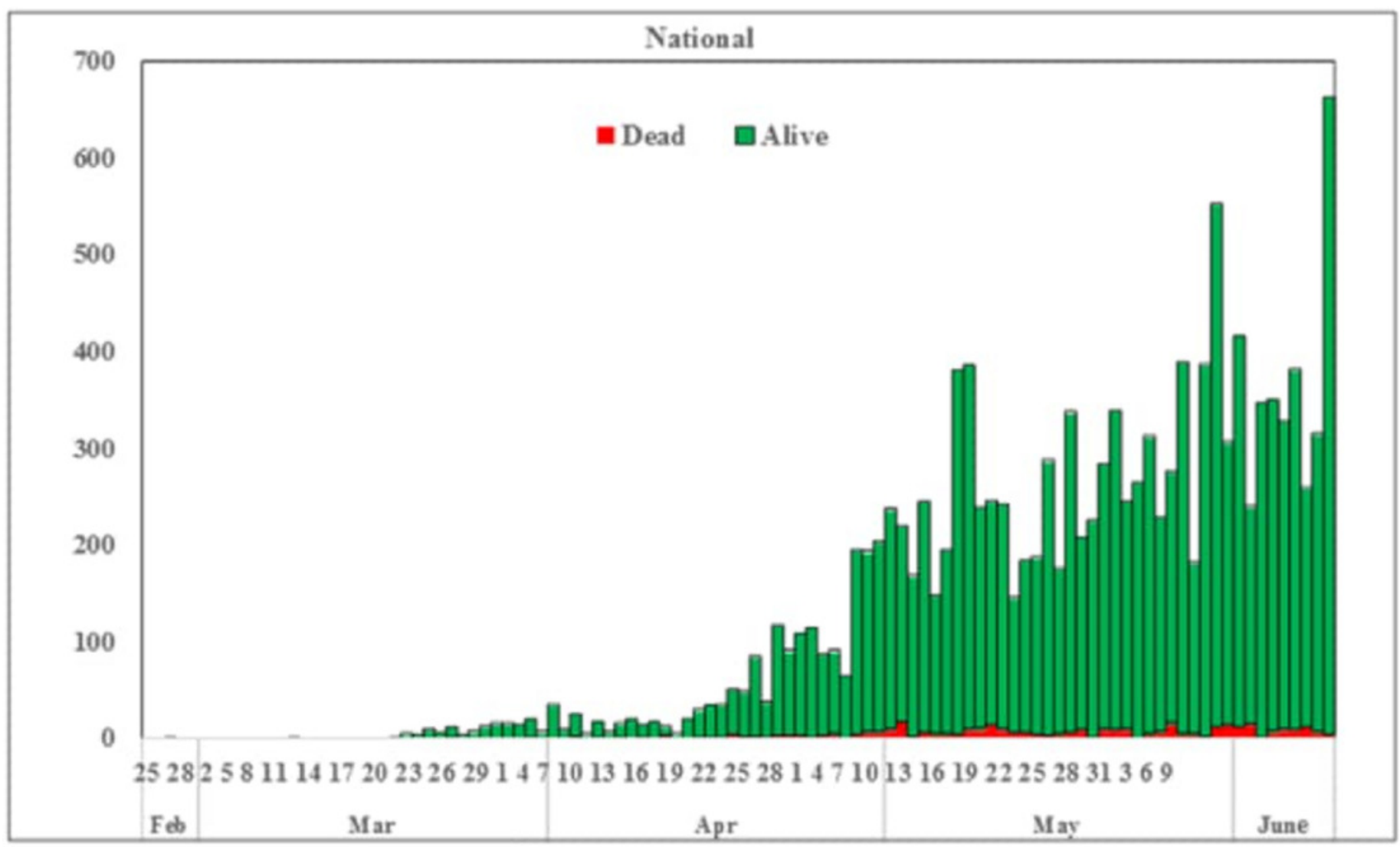

Source: Nigeria Centre for Disease Control (NCDC) 2020. 


\section{Figure 5}

Nitrogen dioxide concentration levels over Lagos and Ibadan during lockdown period April, 10-18, 2020 (A) and pre-lockdown period Dec., 10-14, 2019 (B).
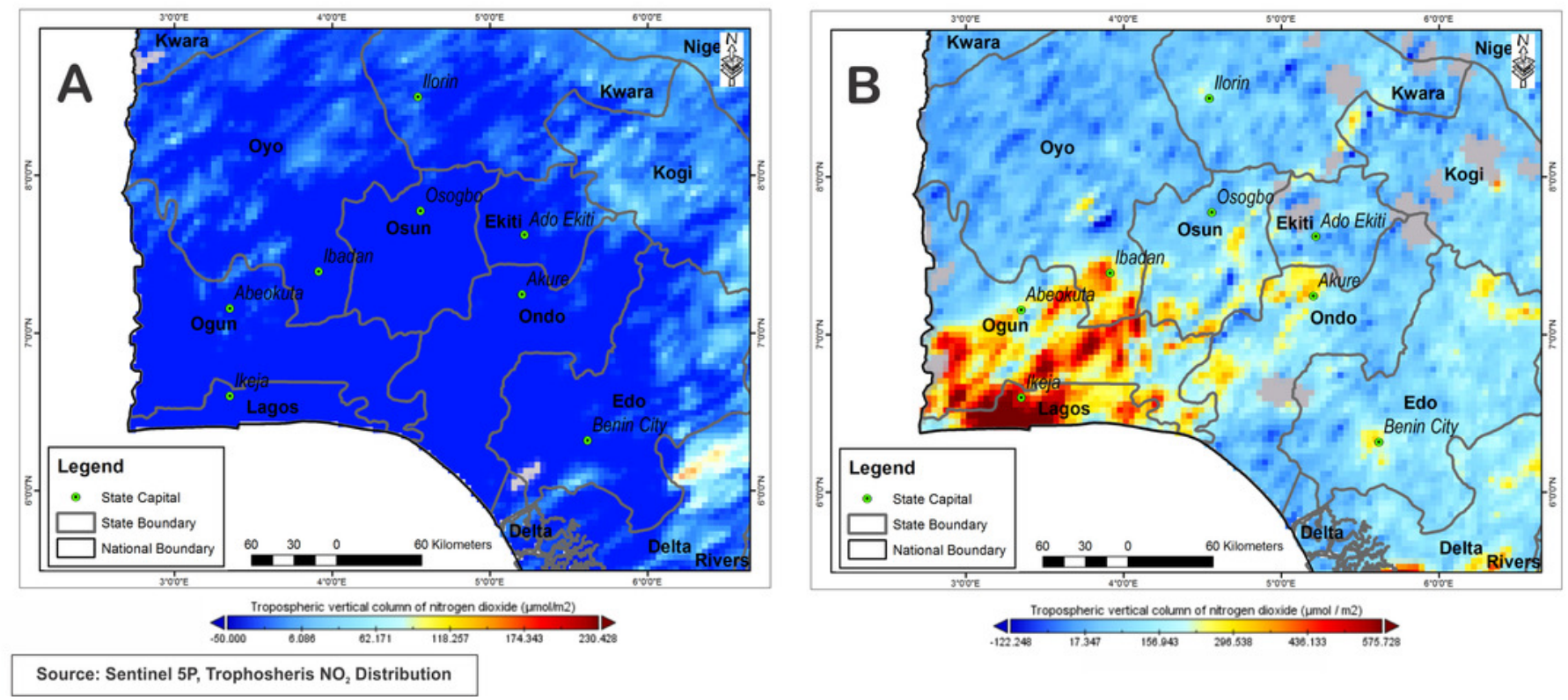


\section{Figure 6}

Nitrogen dioxide concentration levels over Kano during lockdown period April, 10-18, 2020 (A) and pre-lockdown period Dec., 10-14, 2019 (B).
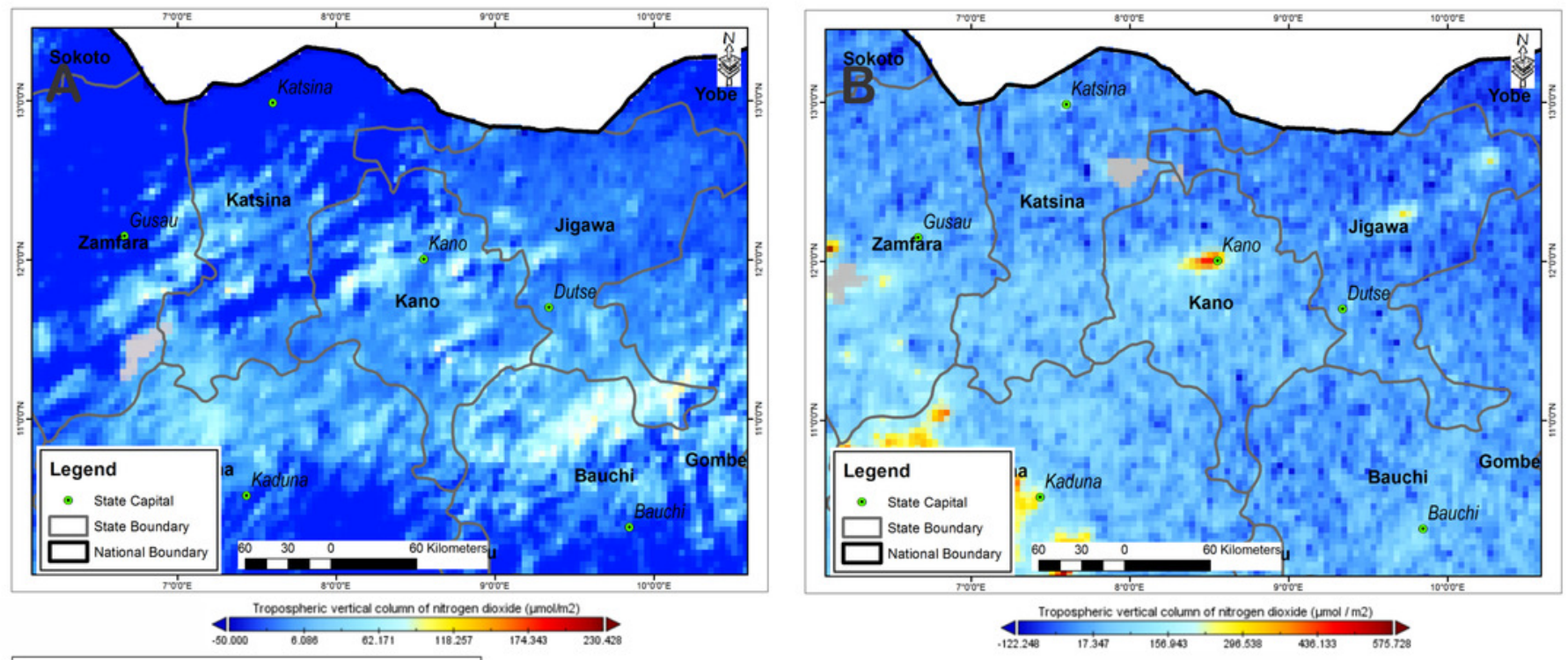

Source: Sentinel 5P, Trophosheris $\mathrm{NO}_{2}$ Distribution 


\section{Figure 7}

Nitrogen dioxide concentration levels over Abuja during lockdown period April, 10-18, 2020 (A) and pre-lockdown period Dec., 10-14, 2019 (B).
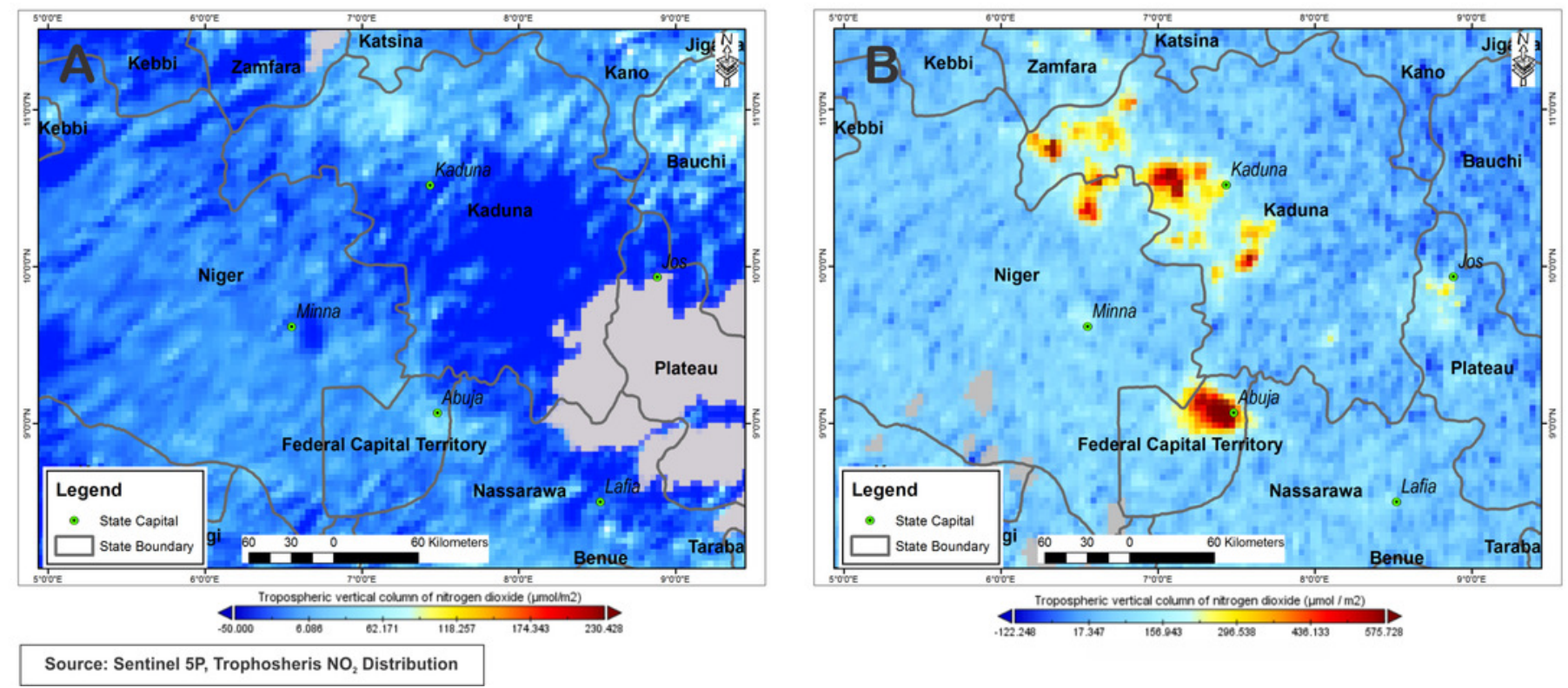
Figure 8

Nitrogen dioxide concentration levels over Owerri and Onitsha during lockdown period April, 10-18, 2020 (A) and pre-lockdown period Dec., 10-14, 2019 (B).
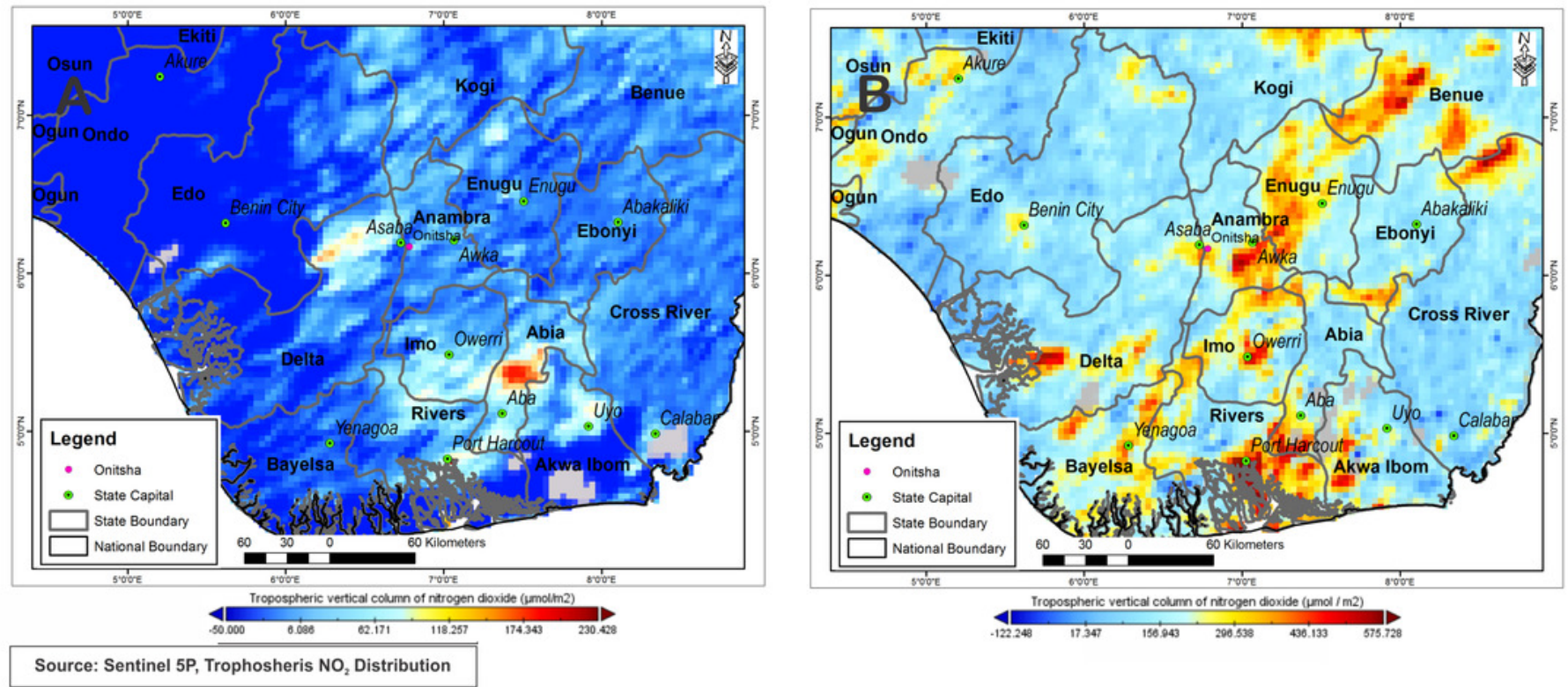